\title{
TECHNOLOGY SELECTION FOR CONSTRUCTION PROJECT, WITH THE USE OF FUZZY PREFERENCE RELATION
}

\section{N. IBADOV ${ }^{1}$, J. ROSLON ${ }^{2}$}

\begin{abstract}
Article deals with the problem of technology selection for construction project. Three criteria were proposed: cost, time and technological complexity. To solve the problem, fuzzy preference relations were used. Authors present an algorithm supporting multi-criteria decision-making process. The algorithm creates fuzzy preference relations on the basis of the fuzzy comparison: " $x_{i}$ is better than $x_{j}$ ". Then, with the use of criteria weights it creates general fuzzy preference relation, finds all non-dominated (admissible) alternatives and the best one among them. The algorithm consists of 7 steps. Authors show application of the proposed algorithm - example calculations.
\end{abstract}

Keywords: technology selection, fuzzy preference relation, construction project planning

\section{INTRODUCTION}

Selection of technology for a construction project is made at the design stage of the project. Developed design solution essentially represent the technology for the object implementation. This information is included, to a large extent, in the technical description of construction object. Yet, it is known, that economic efficiency, and qualitative and quantitative indicators, for both designed and implemented objects, are determined under the assumption, that an appropriate technology for

\footnotetext{
${ }^{1}$ PhD., Eng., Warsaw University of Technology, Faculty of Civil Engineering, Al. Armii Ludowej 16, 00-637 Warsaw, Poland, e-mail: n.ibadov@il.pw.edu.pl

${ }^{2}$ MSc., Eng., Warsaw University of Technology, Faculty of Civil Engineering, Al. Armii Ludowej 16, 00-637 Warsaw, Poland, e-mail: j.roslon@il.pw.edu.pl
} 
conduction of construction works (processes) was selected. In the construction industry, the technology is selected mostly on the basis of experience, intuition, or current "construction trends" (if the client does not dictate a specific type of technology).

In order to achieve reasonable and acceptable technical and economic indicators, the right technology should be selected at the design stage of the project. The technology should be chosen from existing alternatives, available on the market. This requires the selection of appropriate evaluation criteria, specifying the characteristics of the technology [9]. Criteria are then used to preform comparison analysis (evaluation) of alternative technological solutions in order to select the most optimal variant for construction works. In practice, the selection is limited to time and cost criteria. In such case, the optimal technological solution will be characterized by the best cost and/or time indicator.

However, technological processes typically vary in terms of complexity. The complexity may require entrusting execution of works to specialized working brigades supplied with the appropriate equipment. The level of technological complexity may cause additional interference factors in terms of synchronizing tasks, hinder smooth organization of works, etc. This may cause the delays in the planned execution times of individual tasks and increase production costs [5], [15].

Because of that, according to the authors, it is reasonable to take into account (in addition to the time-cost characteristics of the considered technologies) additional criteria that will take into account the priorities and specifics of the decision situation. We propose general criterion: technological complexity. Depending on the decision-making situation, it should cover both technical and market specific aspects of assessed technologies, namely: the difficulty level of preformed works, availability of the materials, availability of qualified workers, availability of necessary machinery and equipment, the level of organizational difficulties, etc.

Using multiple criteria during comparison of alternatives, hinders selection of the objectively optimal solution [2]. In such case it is wise to use one of many available methods supporting decision-making [12], [13], [14]. However, no matter which method is used, the decision-maker has to determine which variant is "better" or "worse" in accordance to established criteria. The traditional way to describe such situation is: $x_{i} R x_{j} \Leftrightarrow x_{i}{ }^{\prime \prime}$ better than" $x_{j}$, where $\mathrm{R}$ is a partial order relation, defined on the elements of the set of compared variants (alternatives) X [8]. It is worth to note, that term "better" and associated with it relations can be defined in many ways. Authors propose to use fuzzy relations, as this linguistic term and quality criteria (in our case the criterion of "technological complexity") are inherently fuzzy concepts. 


\section{FUNDAMENTAL CONCEPTS OF THE FUZZY SETS THEORY}

The concept of a fuzzy set was introduced by L.A. Zadeh [18], as generalization of the conventional or nonfuzzy set concept.. A fuzzy set $A$ in a non-empty space $\mathrm{X}$ is a set of pairs [1]:

$$
A=\left\{\left(x, \mu_{A}(x)\right) ; x \in \mathrm{X}\right\}
$$

where:

$\mu_{A}: \mathrm{X} \rightarrow[0,1]$ is a membership function of the fuzzy set $\mathrm{A}$. For each element $x \in \mathrm{X}$, this function assigns a degree of membership to the fuzzy set A.

Depending on the value of the membership degree, one can distinguish three cases:

1) $\mu_{A}(x)=1$ means that element $\mathrm{x}$ is fully included in fuzzy set $\mathrm{A}, x \in A$,

2) $\mu_{A}(x)=0$ means that element $\mathrm{x}$ is not included in fuzzy set $\mathrm{A}, x \notin A$,

3) $0<\mu_{A}(x)<1$ means that element $\mathrm{x}$ is partially included (fuzzy member) in fuzzy set A.

Figure 1 shows the typical L, $\mathrm{t}$ and $\gamma$ class membership functions [4], [7].

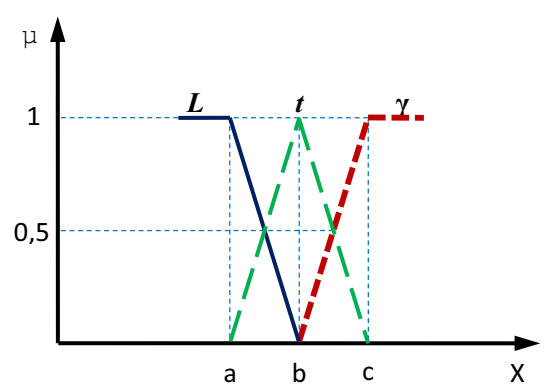

Fig. 1. L, t and $\gamma$ class membership functions

L class function is described by the Eq. (2.2):

$$
L=(x ; a, b)=\left\{\begin{array}{lrrr}
1 & \text { for } & x \leq a \\
\frac{b-x}{b-a} & \text { for } & a \leq x \leq b \\
0 & \text { for } & x \geq b
\end{array}\right.
$$

$\mathrm{t}$ class function is described by the Eq. (2.3): 


$$
t=(x ; a, b, c)=\left\{\begin{array}{lll}
0 & \text { for } & x \leq a \\
\frac{x-a}{b-a} & \text { for } & a \leq x \leq b \\
\frac{c-x}{c-b} & \text { for } & b \leq x \leq c \\
0 & \text { for } & x \geq c
\end{array}\right.
$$

$\gamma$ class function is described by the Eq. (2.4):

$$
\gamma=(x, a, b)=\left\{\begin{array}{lrrr}
0 & \text { for } & x \leq b \\
\frac{x-b}{c-b} & \text { for } & b \leq x \leq c \\
1 & \text { for } & x \geq c
\end{array}\right.
$$

Some denotations and operations on fuzzy sets such as inclusion $(\subset)$, complement of the fuzzy set, or standard intersection $(\cap)$ and standard union $(\cup)$ of fuzzy sets A and B, can be displayed in the following manner [11], [17], [18]:

$$
\begin{gathered}
A \subset B \leftrightarrow \mu_{A}(x) \leq \mu_{B}(x), \forall x \in \mathrm{X}, \\
\mu_{\bar{A}}(x)=1-\mu_{A}(x), \forall x \in \mathrm{X}, \\
\mu_{A \cap B}(x)=\min \left(\mu_{A}(x) \mu_{B}(x)\right), \forall x \in \mathrm{X}, \\
\mu_{A \cup B}(x)=\max \left(\mu_{A}(x) \mu_{B}(x)\right), \forall x \in \mathrm{X} .
\end{gathered}
$$

A very important feature of fuzzy sets is that they can be used for modelling certain imprecise characteristics with the use of linguistic variables, basing on the expert experience [2], [3], [6], [10]. Suppose that the expert determines the unit cost of implementing a work with the use of particular technology, with notions as: "low cost", "average cost" and "high cost". The minimum costs is $3000 \mathrm{PLN} / \mathrm{m} 2$ and the maximum 5000PLN / $\mathrm{m} 2$. The formalization of such a description can be carried out using a linguistic variable characterized by $<\mathrm{N}, \mathrm{T}, \mathrm{X}, \mathrm{G}, \mathrm{M}>$ data set, where:

$\mathrm{N}$ - linguistic variable name, the unit cost for task;

$\mathrm{T}$ - terms (sets) - \{"low cost", "average cost", "high cost"\} - representing a range of meanings for fuzzy variable on universe $\mathrm{X}$; 
$X=[3000,5000]$ - universe, which is a set of alternate unit costs;

$\mathrm{G}$ - syntactic procedure that allows to operate on a terms $\mathrm{T}$, in particular, to generate new terms (meanings). In other words, this is a procedure used for creation of new terms with the use of conjunctions ("and", “or") and modifiers ("very", "more or less", “approximately", etc.). For example: "low or medium cost", "very high cost" and so on;

$\mathrm{M}$ - semantic procedure, which enables one to transform any new value of the linguistic variable created by the G procedure into fuzzy variable, namely establish an appropriate fuzzy set. In other words, this is a procedure that allows to create within universe $\mathrm{X}$ fuzzy subsets $\mathrm{A}_{1}=$ "low cost", $\mathrm{A}_{2}$ $=$ "medium cost", $A_{3}=$ "high cost", and the fuzzy sets for $\mathrm{G}(\mathrm{T})$ terms, according to the rules of fuzzy conjunctions and modifiers transmission. Sets $A_{1}, A_{2}, A_{3}$ can be described with the use of functions shown in figure 1.

In addition to the considered above base values of linguistic variable $\mathrm{T}=\{$ "low cost", "medium cost", "high cost"\} depending on the field of $\mathrm{X}$ other values are also possible. In our case linguistic variable "performance cost" values may be defined as fuzzy numbers, for example " approximately 3000zł", or "approximately 4000zł".

The concept of fuzzy relations allows to assign a degree of a membership to compared elements of a set. The degree defines the relationship (the strength of relation) between them. The a fuzzy relation is a fuzzy set defined on the Cartesian product of crisp sets. A fuzzy relation $R(x, y)$ for two crisp sets $\mathrm{X}$ and $\mathrm{Y}$ can be represented as a set of ordered pairs [16]:

$$
R(x, y)=\left\{(x, y), \mu_{R}(x, y)\right\}, x \in X, y \in Y, \mu_{R}(x, y) \in[0,1]
$$

Thus, a degree of membership is assigned to each pair of elements, defining the relationship between them. If the sets $\mathrm{X}$ and $\mathrm{Y}$ consist of a finite number of elements, fuzzy relationship may be depicted as a matrix [8]:

$$
R_{k}=\left(\begin{array}{cccc}
\mu_{R}\left(x_{1}, y_{1}\right) & \mu_{R}\left(x_{1}, y_{2}\right) & \ldots & \mu_{R}\left(x_{1}, y_{m}\right) \\
\mu_{R}\left(x_{2}, y_{1}\right) & \mu_{R}\left(x_{2}, y_{2}\right) & \ldots & \mu_{R}\left(x_{2}, y_{m}\right) \\
\ldots & \ldots & \ldots & \ldots \\
\mu_{R}\left(x_{k}, y_{1}\right) & \mu_{R}\left(x_{k}, y_{2}\right) & \ldots & \mu_{R}\left(x_{k}, y_{m}\right)
\end{array}\right)
$$


The binary relations may be defined not only on the two sets $\mathrm{X}$ and $\mathrm{Y}$ but also on a single set $\mathrm{X}$. For example, if for a pair $\left(x_{i}, x_{j}\right)$ from set $\mathrm{X}$ we have $\left(x_{i}, x_{j}\right) \in R$, we say that there is a relation $\mathrm{R}$ for the pair $\left(x_{i}, x_{j}\right)$. It is presumed for the fuzzy preference relations that they comply with the conditions of transitivity, consistency and reflexivity, as well as, with other characteristics associated with these conditions and all the operations carried out on fuzzy sets. Let us present only a few selected basic concepts.

Fuzzy relationship is transitive if [16]:

$$
\mu_{R}\left(x_{i}, x_{k}\right) \geq \max \min \left[\mu_{R}\left(x_{i}, x_{j}\right), \mu_{R}\left(x_{j}, x_{k}\right)\right]
$$

Transitivity is one of the basic features of rational preference relation. A fuzzy binary relation $\mathrm{R}$ is symmetric, if for any $x_{i}, x_{j} \in X, \mu_{R}\left(x_{i}, x_{j}\right)=\mu_{R}\left(x_{j}, x_{i}\right)$ and antisymmetric if $\mu_{R}\left(x_{i}, x_{j}\right)>0$, then $\mu_{R}\left(x_{j}, x_{i}\right)=0$. An example of symmetric fuzzy relation is an equivalence relation - relation of alternatives indifference. A fuzzy relation is reflexive, if for all $\mathrm{x}, 0<\mathrm{k}<1, \mu_{R}(x, x) \geq k$. The operation of fuzzy binary relation $R_{1}$ and $R_{2}$ intersection on the set $\mathrm{X}$ is called a fuzzy binary relation $R$ with a membership function [16]:

$$
\mu_{R}(x, y)=\sup _{z \in X} \min \left[\mu_{R_{1}}(x, z) ; \mu_{R_{2}}(z, y)\right]
$$

Basin on the fuzzy relation $\mathrm{R}$, one can determine a strong preference fuzzy relation $R^{s p}$. Such relation can be determined in the following manner [16]:

$$
\mu_{R}^{s p}(x, y)=\left\{\begin{array}{l}
\mu_{R}(x, y)-\mu_{R}(y, x), \text { if } \mu_{R}(x, y) \geq \mu_{R}(y, x), \\
0, \text { in other case }
\end{array}\right.
$$

Fuzzy preference relation allows for alternatives preferability comparison. If on the set of alternatives, there is established a fuzzy preference relation $\mathrm{R}$, than during process of decision making, it is determined which of the alternatives is best, from decision maker's point of view. Such alternatives are being called: non-dominated (admissible). 
If we define the set of alternatives by $\mathrm{X}$ and its fuzzy preference relations' membership functions by $\mu_{R}$, than fuzzy subset of non-dominated alternatives for set $\left(\mathrm{X}, \mu_{R}\right)$ can be described by following membership function [16]:

$$
\mu_{R}^{n d}=1-\sup _{x, y \in X}\left(\mu_{R}(y, x)-\mu_{R}(x, y)\right)
$$

Using the above presented formulas and operations on fuzzy sets, one can solve the task of selecting the technology for construction works and create a preference hierarchy of alternatives, taking into account multiple evaluation criteria.

\section{ALGORITHM FOR SOLVING THE TASK OF TECHNOLOGY VARIANT SELECTION - DESCRIPTION}

Let us assume, that on the set of alternatives (construction works technologies) $X=\left\{x_{i}\right\}$ there are fuzzy preference relations $\mathrm{R} 1, \mathrm{R} 2, \ldots \mathrm{Rm}$ with appropriate membership functions $\mu_{R}\left(x_{i}, x_{j}\right)$, and relations weights $w_{k}$ which result from the weight of assessment criteria. One has to choose the best alternative from the set $\left\{X, R_{k}\right\}$.

The solution can be obtained in following manner [2], [8], [10]:

1. Create $n \times n$ matrices for relations $\mathrm{R}_{1}, \mathrm{R}_{2}, \ldots \mathrm{R}_{\mathrm{m}}$ with membership functions $\mu_{R}\left(x_{i}, x_{j}\right)$ with the use of Eq. (3.1):

$$
\mu_{R}\left(x_{i}, x_{j}\right)=\left\{\begin{array}{l}
1, \text { if } x_{i} \geq x_{j} \text { or } x_{i} \approx x_{j} \\
0, \text { if } x_{i} \prec x_{j}
\end{array}\right.
$$

2. Create a fuzzy relation $P_{1}=R_{1} \cap R_{2} \cap \ldots \cap R_{m}$. It is a $n \times n$ matrix, which elements $\mu_{P_{1}}\left(x_{i}, x_{j}\right)$ are described by Eq. (3.2):

$$
\mu_{P_{1}}\left(x_{i}, x_{j}\right)=\min \left\{\mu_{1}\left(x_{i}, x_{j}\right), \ldots, \mu_{m}\left(x_{i}, x_{j}\right)\right\}
$$


3. Define a subset of non-dominated alternatives $x_{i}$ in the $\left\{X, P_{1}\right\}$ set, as in Eq. (3.3):

$$
\mu_{P_{1}}^{n d}\left(x_{i}\right)=1-\sup _{x_{j}}\left[\mu_{P}\left(x_{j}, x_{i}\right)-\mu_{P}\left(x_{i}, x_{j}\right)\right]
$$

4. Create a $n \times n$ matrix for fuzzy relation $\mathrm{P}_{2}$. Weight criteria $w_{k}$ of the matrix are as in Eq. (3.4):

$$
\mu_{P}\left(x_{i}, x_{j}\right)=\sum_{k=1}^{m} w_{k} \mu_{k}\left(x_{i}, x_{j}\right)
$$

5. Define a subset of non-dominated alternatives $x_{i}$ in the $\left\{X, P_{2}\right\}$ set, as in Eq. (3.5):

$$
\mu_{P_{2}}^{n d}\left(x_{i}\right)=1-\sup _{x_{j}}\left[\mu_{P_{2}}\left(x_{j}, x_{i}\right)-\mu_{P_{2}}\left(x_{i}, x_{j}\right)\right]
$$

This function hierarchize alternatives in accordance to their degree of admissibility.

6. Find intersection of membership functions $\mu_{P_{1}}^{\text {nd }}$ and $\mu_{P_{2}}^{\text {nd }}$ in accordance with Eq. (3.6):

$$
\mu^{n d}\left(x_{i}\right)=\min \left\{\mu_{P_{1}}^{n d}\left(x_{i}\right), \mu_{P_{2}}^{n d}\left(x_{i}\right)\right\}
$$

where:

$\mu^{n d}\left(x_{i}\right)$ is a degree of admissibility for alternative $x_{i}$. It means that the higher the value of $\mu^{n d}\left(x_{i}\right)$, the "better" the alternative $x_{i}$.

7. The choice of the best alternative from the set $X_{n d}$ is made by the use of Eq. (3.7):

$$
\mu^{n d}(x)=\sup _{x \in X}\left\{\mu^{n d}\left(x_{i}\right)\right\}
$$

The application of the presented algorithm is shown in the following chapter. 


\section{ALGORITHM - EXAMPLE OF APPLICATION}

Construction company needs to select technology of basic works for a construction project. There is a set of possible technologies - alternatives: $X=\left(x_{1}, x_{2}, \ldots, x_{n}\right)$. The company assess them on the base of following criteria: $\mathrm{K}_{1}$ - cost, $\mathrm{K}_{2}$ - duration (time), $\mathrm{K}_{3}$ - technological complexity.

Let us assume that all criteria are presented by adequate fuzzy sets (for example: technological complexity $=\{$ low, medium, high $\}$ ) and described by membership functions as in Eq. (2.2), (2.3) and (2.4). According to the expert assessment, on the base of used criteria following preference relations are created on the set of alternative technologies $\mathrm{X}$ :

$$
\begin{aligned}
& R_{1}: x_{1} \succ x_{2}, x_{2} \succ x_{3}, x_{3} \succ x_{4}, \\
& R_{2}: x_{1} \succ x_{2}, x_{3} \succ x_{4}, x_{4} \succ x_{1}, \\
& R_{3}: x_{1} \succ x_{3}, x_{3} \succ x_{4}, x_{4} \succ x_{2},
\end{aligned}
$$

It is crucial to reach a compromise when it comes to chosen criteria. It can be obtained by the composition of preference relations $\mathrm{P}_{1}$ and $\mathrm{P}_{2}$. Set criteria weights are: $w_{1}=0,4 ; w_{2}=0,3 ; w_{3}=0,3$.

Assuming fulfilment of transitivity condition, matrices for relations $R_{1}, R_{2}, R_{3}$ are created with the use of Eq. (3.1):

Preference relation $\mathrm{R}_{1}$ matrix:

$\mu_{R_{1}}\left(x_{i}, x_{j}\right)=\begin{array}{ccccc} & x_{1} & x_{2} & x_{3} & x_{4} \\ x_{1} & 1 & 1 & 1 & 1 \\ x_{2} & 0 & 1 & 1 & 1 \\ x_{3} & 0 & 0 & 1 & 1 \\ x_{4} & 0 & 0 & 0 & 1\end{array}$

Preference relation $\mathrm{R}_{2}$ matrix:

$$
\mu_{R_{2}}\left(x_{i}, x_{j}\right)=\begin{array}{ccccc} 
& x_{1} & x_{2} & x_{3} & x_{4} \\
x_{1} & 1 & 1 & 0 & 0 \\
x_{2} & 0 & 1 & 0 & 0 \\
x_{3} & 1 & 1 & 1 & 1 \\
x_{4} & 1 & 1 & 0 & 1
\end{array}
$$


Preference relation $\mathrm{R}_{3}$ matrix:

$$
\mu_{R_{3}}\left(x_{i}, x_{j}\right)=\begin{array}{ccccc} 
& x_{1} & x_{2} & x_{3} & x_{4} \\
x_{1} & 1 & 1 & 1 & 1 \\
x_{2} & 0 & 1 & 0 & 0 \\
x_{3} & 0 & 1 & 1 & 1 \\
x_{4} & 0 & 1 & 0 & 1
\end{array}
$$

The next step is to create $P_{1}$ relation matrix, which is an intersection of relations $R_{1}, R_{2}, R_{3}$ with adequate $\mu_{P_{1}}\left(x_{i}, x_{j}\right)$ elements. $\mathrm{P}_{1}$ is depicted in Eq. (4.5):

$$
\mu_{P_{1}}\left(x_{i}, x_{j}\right)=\begin{array}{rcccc} 
& x_{1} & x_{2} & x_{3} & x_{4} \\
x_{1} & 1 & 1 & 0 & 0 \\
x_{2} & 0 & 1 & 0 & 0 \\
x_{3} & 0 & 0 & 1 & 1 \\
x_{4} & 0 & 0 & 0 & 1
\end{array}
$$

With the use of Eq. (3.3) we find a subset of non-dominated alternatives $x_{i}$ in the $\left\{X, P_{1}\right\}$ set:

$$
\mu_{P_{1}}^{n d}(x)=\left[1 / x_{1} ; 0 / x_{2} ; 1 / x_{3} ; 0 / x_{4}\right]
$$

Taking into account criteria weights, we create a $n \times n$ matrix for fuzzy relation $\mathrm{P}_{2}$ :

$$
\mu_{P_{2}\left(x_{i}, x_{j}\right)=} \begin{array}{ccccc}
x_{1} & x_{2} & x_{3} & x_{4} \\
x_{1} & 1 & 1 & 0,7 & 0,7 \\
x_{2} & 0 & 1 & 0,4 & 0,4 \\
x_{3} & 0,3 & 0,6 & 1 & 1 \\
x_{4} & 0,3 & 0,6 & 0 & 1
\end{array}
$$

With the use of Eq. (3.5) we find a subset of non-dominated alternatives $x_{i}$ in the $\left\{X, P_{2}\right\}$ set:

$$
\mu_{P_{2}}^{\text {nd }}(x)=\left[1 / x_{1} ; 0 / x_{2} ; 0,6 / x_{3} ; 0 / x_{4}\right]
$$


Finally, we find intersection of membership functions $\mu_{P_{1}}^{n d}$ and $\mu_{P_{2}}^{\text {nd }}$ for non-dominated alternatives P1 and P2 - Eq. (4.9). According to that equation that the best alternative is $x_{1}$.

$$
\mu^{n d}(x)=\min \left\{\mu_{P_{1}}^{n d}(x), \mu_{P_{2}}^{n d}(x)\right\}=\left[1 / x_{1} ; 0 / x_{2} ; 0,6 / x_{3} ; 0 / x_{4}\right]
$$

\section{Conclusions}

Construction projects require series of work processes that differ in terms of technology and management. There are also many assessment criteria for evaluation of these projects. However, choice of technology, to a large extent, affect the construction process organization, which has a significant impact on the duration and direct cost of the project. Therefore, it seems reasonable to adapt criteria different from cost and time - technological complexity of construction works. At the design stage of the construction project, such criterion allows for consideration of uncertainty of the possible threats that may occur during construction works. This uncertainty does not have a stochastic character. Therefore, using fuzzy set theory is a good way to solve this problem.

Another advantage of the proposed algorithm is that at the design stage, due to the high uncertainty level, the decision-maker may not have well-defined preferences. In such case use of fuzzy preference relation allows for a better way of formalizing and describing the decision-making situation.

The proposed method allows for selection of the most rational variant for construction works, taking into account predefined criteria and their weights. At the same time, on the basis of admissibility of the alternatives, method enables creation of preferences, which shows how strongly the other variants differ from each other. This fact can be very helpful, when for any reason one has to choose the second best option. In the presented example the best technology variant was $x_{I}$, followed by alternative $x_{3}$. 


\section{REFERENCES}

1. N. Ibadov, "Fuzzy estimation of activities duration in construction projects", Archives of Civil Engineering. Vol. LXI, ISSUE 2/2015, pp. 23-34.

2. N. Ibadov, "Contractor selection for construction project, with the use of fuzzy preference relation", XXIV RS-P seminar, Theoretical Foundation of Civil Engineering, Published by Elsevier Ltd. Procedia Engineering 111 ( 2015 ) pp. $317-323$.

3. N. Ibadov, J. Kulejewski, "Wybór dostawcy w realizacji przedsięwzięcia budowlanego przy nieprecyzyjnie określonych kryteriach oceny”, Logistyka (ISSN 1231-5478), nr 3/2014, str. 2384-2388.

4. N. Ibadov, J. Kulejewski, "Rozmyte modelowanie czasów wykonania robót budowlanych w warunkach niepewności”, Czasopismo Techniczne. Wydawnictwo PK, Budownictwo, Rocznik 2010, Tom R. 107, z. 1-B, str. 139-155.

5. N. Ibadov, J. Kulejewski, M. Krzemiński, "Fuzzy ordering of the factors affecting the implementation of construction projects in Poland". AIP Conference proceedings, Vol. 1558, 2013, pp. 1298-1301.

6. N. Ibadov, J. Kulejewski, "The assessment of construction project risks with the use of fuzzy sets theory", Czasopismo Techniczne, Wydawnictwo PK, Budownictwo Zeszyt 1-B (5) 2014, s. 175-182.

7. N. Ibadov, "Wielokryterialna ocena procesów budowlanych $\mathrm{z}$ uwzględnieniem rozmytego modelowania niepewności aspektów technologicznych". Autobusy (ISSN 1509-5878): technika, eksploatacja, systemy transportowe 2013, nr 3. Tom 14, Str. 1183-1191.

8. N. Ibadov, "Wielokryterialny wybór wariantów wykonania przedsięwzięć budowlanych na podstawie rozmytej relacji preferencji”. Logistyka 6/2014, Pełny tekst na CD3 str. 4564-4569.

9. N. Ibadov, "Wybór wariantu przedsięwzięcia budowlanego przy rozmytym modelowaniu ryzyka technologiczno-organizacyjnego". "Theoretical Foundations of Civil Engineering" Polish - Ukrainian Transactions, vol.21, Oficyna Wydawnicza PW, Warszawa 2013, str. 405-412.

10. N. Ibadov, "Wybór dostawcy w przedsięwzięciach budowlanych na podstawie rozmytej relacji preferencji", Logistyka 3/2015, Pełny tekst na CD1 str. 1823-1829.

11. J. Kasprzyk, “Zbiory rozmyte w analizie systemowej”, PWN, Warszawa 1986.

12. M. Książek, P. Nowak, S. Kivrak, J. Rosłon, L. Ustinovichius, "Computer-aided decision-making in construction project development", Journal of Civil Engineering and Management, 2015, vol. 21 (2), pages: 248-259, ISSN 1392-3730.

13. M. Książek, P. Nowak, J. Rosłon, T. Wieczorek, "Multicriteria Assessment of Selected Solutions for the Building Structural Walls“, XXIII R-S-P seminar, Theoretical Foundation of Civil Engineering (23RSP), Procedia Engineering, 2014, vol. 91, pages: 406-411, ISSN: 1877-7058.

14. M. Książek, P. Nowak, J. Rosłon, "Ocena wielokryterialna wybranych rozwiązań konstrukcyjnych stropów", Logistyka, 2014, vol. 6, ISSN 1231-5478.

15. A. Nicał, „Analiza wybranych ryzyk przy produkcji prefabrykatów betonowych” (eng. „Risk analysis of selected aspects of the concrete prefabricates production"). Logistyka nr 3/2015, p. 3479-3486 (in Polish).

16. S.A. Orlovsky, "Decision making under fuzzy initial information", Moscow " Nauka". Home Edition of Physical and Mathematical literature, Moscow 1981. (in Russian).

17. L. Rutkowski, "Metody i techniki sztuczniej inteligencji”, PWN, Warszawa 2006.

18. L.A. Zadeh, "Fuzzy Sets", Information and Control, 1965, vol. 8. pp. 338-353.

\section{LIST OF FIGURES AND TABLES:}

Fig. 1. L, $\mathrm{t}$ and $\gamma$ class membership functions

Rys. 1. Funkcje przynależności klasy L, t i $\gamma$ 


\title{
WYBÓR WARIANTU TECHNOLOGICZNEGO REALIZACJI PROCESÓW BUDOWLANYCH Z ZASTOSOWANIEM ROZMYTEJ RELACJI PREFERENCJI
}

\author{
Slowa kluczowe: wybór technologii robót budowlanych, rozmyta relacja preferencji, planowanie przedsięwzięcia \\ budowlanego
}

\section{STRESZCZENIE:}

$\mathrm{Na}$ etapie projektowania architektoniczno-budowlanego zakłada się rodzaj technologii wykonania obiektu budowlanego. Opracowane rozwiązania projektowe w zasadzie przedstawiają w jakiej technologii dany obiekt zostanie realizowany. Informacje te $\mathrm{w}$ dużej mierze zawarte są w opisie technicznym obiektu budowlanego. Tym czasem wiadomo, że ekonomiczną efektywność oraz jakościowe i ilościowe wskaźniki projektowanych i realizowanych obiektów, określa się przy założeniu właściwiej technologii prowadzenia robót (procesów) budowlanych. W praktyce budowlanej w dużej mierze technologię wybiera się w oparciu o doświadczenie, intuicję lub też w oparciu o „modę” budowania, jeśli oczywiście zamawiający z góry nie narzuci rodzaju technologii.

W celu uzyskania racjonalnych i akceptowalnych wskaźników techniczno-ekonomicznych należy jeszcze na etapie projektowania dokonać wyboru właściwej technologii wykonania robót budowlanych spośród istniejących, dostępnych w danym ryku alternatywnych rodzajów technologii. Wymaga to doboru odpowiednich kryteriów oceny, określające cechy charakterystyczne danej technologii. A następnie przeprowadzenia analizy (oceny) porównawczej alternatywnych rozwiązań technologicznych i wybrania najbardziej optymalnego wariantu wykonania robót.

W praktyce najczęściej ogranicza się do oceny czasowej i kosztowej. W tym zakresie optymalne rozwiązanie technologiczne to to, które charakteryzuje się najkorzystniejszym wskaźnikiem kosztu i/lub czasu realizacji. Tymczasem procesy technologiczne maja zazwyczaj strukturę o różnej złożoności. Złożoność ta wymaga powierzenie ich wykonanie specjalistycznym brygadom roboczym, wyposażonym w odpowiedni sprzęt. Stopień złożoności technologicznej może powodować dodatkowe czynniki zakłócające w zakresie synchronizacji robót poszczególnych specjalności, utrudniać płynnej organizacji robót itd. Fakt ten może powodować, wydłużenie planowanych czasów realizacji poszczególnych robót i zwiększenie kosztów produkcji.

W związku z czym, zdaniem autorów zasadne jest uwzględnienie oprócz czasowo kosztowych charakterystyk rozważanych technologii jeszcze dodatkowych kryteriów, maksymalnie uwzględniające priorytety danej sytuacji decyzyjnej. Może to być ogólnie sformułowane kryterium złożoności technologicznej w zakresie którym w zależności od sytuacji decyzyjnej należy uwzględniać aspekty czysto techniczne jak i rynkowe, a mianowicie: stopień trudności wykonania robót $\mathrm{w}$ danej technologii, dostępność materiałów zastosowanych w danej technologii, dostępność wykwalifikowanych specjalistów w zakresie wybranej technologii, dostępność potrzebnych maszyn i urządzeń w danej technologii, stopień trudności organizacji robót w danej technologii itd. Uwzględnienie w analizie (ocenie) porównawczej wiele kryteriów utrudnia podejmowanie decyzji obiektywnie optymalnych. W celu ułatwiania podejmowania decyzji, autorzy proponują zastosować relację rozmytą. Zwłaszcza, że lingwistycznie określenie używane do porównań „lepsze” oraz kryteria jakościowe (w naszym przypadku kryterium „złożoność technologiczna”) są z natury pojęciami rozmytymi. 
Załóżmy, że na zbiorze alternatyw (technologii wykonania robót budowlanych), ustalone są rozmyte relacje preferencji z odpowiednimi funkcjami przynależności oraz wagi odpowiednich relacji, wynikające z ważności kryteriów oceny. W celu rozwiązania problemu, należy wybrać najlepszą alternatywę ze zbioru.

Rozwiązania takiego zadania dokonujemy według poniższego postępowania:

1. Tworzymy macierze poszczególnych relacji $R_{1}, R_{2}, R_{3}$ (dla każdego kryterium) $z$ odpowiednimi funkcjami przynależności.

2. Tworzymy rozmytą relację $P_{1}$ będącą przecięciem poszczególnych relacji $R_{1}, R_{2}, R_{3}$.

3. Określamy podzbiór niezdominowanych alternatyw $\mathrm{x}_{\mathrm{i}} \mathrm{w}$ zbiorze $\left\{X, P_{1}\right\}$.

4. Tworzymy macierz rozmytej relacji $\mathrm{P}_{2} \mathrm{z}$ uwzględnieniem wag kryteriów.

5. Określamy podzbiór niezdominowanych alternatyw $\mathrm{x}_{\mathrm{i}} \mathrm{w}$ zbiorze $\left\{X, P_{2}\right\}$.

6. Znajdujemy przecięcie funkcji przynależności.

7. Dokonujemy wyboru najlepszej alternatywy (najbardziej racjonalnej według przyjętej zasady oceny i ważności kryteriów).

Artykuł zawiera szczegółowy opis algorytmu, wraz z zapisem matematycznym oraz przykładem obliczeniowym.

W opisanym przykładzie firma budowlana potrzebuje wybrać technologie realizacji podstawowych robót budowlanych. Stosuje przy tym następujące kryteria:

- K1- kryterium kosztu wykonania w technologii xi w przeliczeniu na jednostkową ilość roboty;

- K2- czas trwania (pracochłonność) wykonania robót w technologii xi jednostkowej ilości robót;

- K3-złożoność technologiczna realizacji robót w wybranej technologii xi .

Wszystkie kryteria są przedstawione odpowiednim zbiorem rozmytym (na przykład: złożoność technologiczna $=\{$ niska, średnia, wysoka\}) i opisane odpowiednią funkcja przynależności.

Zastosowanie zaproponowanego algorytmu pozwala na w mniejszym lub większym stopniu uwzględnienie niepewności istniejącej na etapie projektowania co do zakresu ewentualnych zagrożeń w procesie realizacji danej roboty. Z kolei niepewność ta nie ma stochastycznego charakteru. Dlatego też zastosowanie elementów teorii zbiorów rozmytych jest dobrym sposobem rozwiązania tego problemu.

Kolejnym istotnym elementem jest to, że na etapie projektowania z uwagi na dużą niepewność, decydent może nie mieć ściśle określonych preferencji. W takiej sytuacji, zastosowanie rozmytej relacji preferencji do wyboru wariantów jest lepszym sposobem pozwalającym sformalizować i opisać sytuację decyzyjną.

Proponowana w artykule metoda pozwala na wybór najbardziej racjonalnego wariantu wykonania robót (procesów) budowlanych przy ustalonych rodzajach i wagach kryteriów oceny. Metoda ta jednocześnie pozwala stworzyć preferencje na podstawie stopnia niezdominowalności wariantów, co ilustruje jak silnie kolejne warianty różnią się od siebie. Ma to duże znaczenie w przypadku konieczności wyboru następnego wariantu. 